\title{
The apoptotic paradox in schizophrenia
}

\section{Şizofrenide apoptotik paradoks}

\author{
Hüseyin Aydın', Yusuf Kenan Tekinn², Serpill Erşan ${ }^{3}$, Hayrettin Yavuz ${ }^{1}$, Ethem Erdal Erşan ${ }^{4}$
}

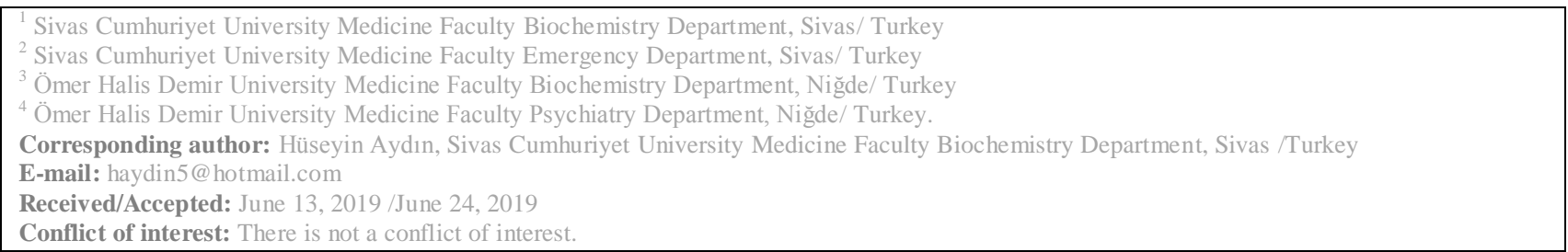

Conflict of interest: There is not a conflict of interes

\begin{abstract}
Objective: Understanding the role of apoptosis in abnormal neurodevelopment and neurodegenerative processes are crucial. In this study, it is aimed to determine how apoptosis biomarkers are affected in patients with schizophrenia and severity of the disease and also whether apoptosis biomarkers can be used as blood-based biomarkers in the diagnosis of the disease.
\end{abstract}

Method: This is a cross-sectional prospective study performed at a tertiary university hospital and city hospital in Turkey. Volunteers $(n=60)$ diagnosed with schizophrenia were divided into three groups (Mild, Moderate, and Severe) according to the Clinical Global Impressions Scale developed by Guy. The control group was constituted from volunteers who were similar to the patient group $(n=40)$ in terms of age and gender. Serum levels of Caspase-8(C-8), Granzyme B (GrB) and Cytochrome C (CYCS) were measured by ELISA method from blood samples collected from patient and control groups.

Results: It was observed that Caspase 8 and GrB levels were lower in all three groups compared with the control group, and the highest decrease was in the 3rd group $(\mathrm{P}<0, .5)$. CYCS level, on the other hand increased, and the highest increase was observed in 3 rd Group $(\mathrm{P}<0.05)$.

Conclusions: It is hypothesized that the increase in serum CYCS level of patients with schizophrenia may be a blood-based biomarker in which apoptosis occurs.

Keywords: Schizophrenia, apoptosis, Caspase-8, Granzyme-B,

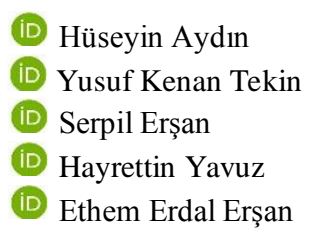

ORCID IDs of the authors: H.A. 0000-0002-3194-830X Y.K.T. 0000-0001-8047-4836 S.E. 0000-0002-8968-4044 H.Y. 0000-0001-5190-7022 E.E.E. 0000-0002-7104-2908

\section{ÖZET}

Amaç: Anormal nörogelişimdeki ve nörodejeneratif süreçlerdeki apoptozisin rolünü anlamak çok önemlidir. Bu çalışmada, şizofreni hastalarında apoptoz biyobelirteçlerinin nasıl etkilendiğini ve hastalığın ciddiyetini ve apoptoz biyobelirteçlerinin hastalığın tanısında kan bazlı biyobelirteçler olarak kullanılıp kullanılamayacağını belirlemek amaçlanmıştır.

Yöntem: Bu, Türkiye'deki bir üniversite hastanesinde ve şehir hastanesinde gerçekleştirilen kesitsel prospektif bir çalışmadır. Şizofreni tanısı alan gönüllüler (n = 60), Guy tarafından geliştirilen Klinik Global İzlenim Ölçeğine göre üç gruba (Hafif, Orta ve Şiddetli) ayrılmıştır. Kontrol grubu, yaş ve cinsiyet açısından hasta grubuna $(\mathrm{n}=40)$ benzeyen gönüllülerden oluşturulmuştur. Serum Caspase-8 (C-8), Granzyme B (GrB) ve Cytcochrome C (CYCS) düzeyleri, hasta ve kontrol gruplarından toplanan kan örneklerinden ELISA yöntemiyle değerlendirildi. 
Bulgular: Caspase 8 ve GrB düzeylerinin her üç grupta da kontrol grubuna göre daha düşük olduğu ve en yüksek düşüşün 3. grupta olduğu gözlendi $(P<0,5)$. Öte yandan, CYCS düzeyi arttı ve 3. grupta en yüksek artış gözlendi (P $<0.05)$.

Sonuç: Şizofreni hastalarında serum CYCS düzeyindeki artışın, apoptozisin meydana geldiği kan bazlı bir biyobelirteç olabileceği varsayılmaktadır.

Anahtar sözcükler: Schizophrenia, apoptosis, Caspase-8, Granzyme-B, Cytochrome C

\section{INTRODUCTION}

Schizophrenia is a chronic mental disorder related to disability. ${ }^{1}$ It is a clinical syndrome characterized by relapses, changing of behavior, progressing with significant hallucinations or deliriums. $^{2}$ The disease is an incurable neurodegenerative disorder, the prevalence of which is one percent of the world population. ${ }^{3}$ The onset of the disease is usually in teens progressing with disorders in areas such as self-care, interpersonal relationships, cognitive abilities, sensation, thought, behavior and perception. ${ }^{4}$ The patients are significantly affected in terms of bilateral relationships.

Studies on the etiology of schizophrenia have aroused the interest of many researchers. Neural and glial abnormalities, which may be the basis of the etiology of schizophrenia, have been investigated for years. Many researchers, including Dr. Alzhemier, have aimed to find microscopic evidence in the patients. In recent years, advances in imaging technology (SPECT, PET, CT, and MRI) have contributed significantly to show changes in the brain. ${ }^{5,6}$ However, neuroimaging techniques are expensive, and the results are not satisfactory. It is suggested that determination of new biomarkers in schizophrenia can be proposed as a contributing mechanism for diagnosis, treatment response, determining changes in the severity and course of the disease, as well as for new drug development efforts. For this reason, researches on blood-based biomarkers to be used in the diagnosis of schizophrenia have increased recently.

Apoptosis is a biochemical process that enables the control and programmed cell death selectively in multicellular organisms, both in embryonal development and in damaged, infected cells. Apoptosis is responsible for destroying damaged neurons during fetal brain development as well as for the lifelong regulation of death of $20 \%-80 \%$ of neurons. $^{7}$

Apoptosis is controlled by complex molecular cascade through activation of the cysteine protease family known as caspase proteins. Caspases are the underlying causes of breaking down vital structural and functional proteins, thereby causing characteristic cytomorphology associated with apoptosis. Apoptosis always starts with a signal. This signal can come from inside the cell itself (intrinsic pathway) or from the environment (extrinsic pathway). Cytochrome C (CYCS) is a mitochondrial protein found in plasma during pro-apoptotic conditions. Even though many molecular pathways have been identified, causing activation of caspases, mitochondrial (intrinsic pathway) pathway is mostly associated with neural apoptosis. The proand anti-apoptotic members of the Bcl-2 protein family regulate caspase activity by controlling the mitochondrial release of cytochrome c. ${ }^{8-10}$ Apoptotic activity can be induced by stimulants such as oxidative stress (ischemia, hypoxia, etc.), pro-inflammatory cytokines, mitochondrial dysfunction, and increased intracellular calcium concentration. ${ }^{11}$

Irregular cell death can cause too many clinical disorders. Excessive apoptosis can lead to ischemic and neurodegenerative damage, while insufficient apoptosis can cause pathological diseases such as cancer and autoimmune diseases. Moreover, apoptosis plays an important role in abnormal neurodevelopment and neurodegenerative processes. ${ }^{12-14}$

It is still not known how programmed cell death (apoptosis) is affected in schizophrenia, which is a neurodegenerative disease. In this study, the levels of apoptosis biomarkers (Caspase-8, GrB, and cytochrome C) will be measured from blood samples collected from patients diagnosed with schizophrenia and divided into 3 groups (Mild, Moderate and Severe) in accordance with Clinical Global Impressions Scale.

This study aimed to determine whether apoptosis biomarkers can be used as a blood-based biomarker in the diagnosis of the schizophrenia.

\section{MATERIAL AND METHODS}

Sixty patients who were diagnosed with schizophrenia according to DSM-V criteria, who were admitted to Sivas Numune Hospital Psychiatry polyclinic and were followed up for at least two years with the diagnosis of schizophrenia, were included in the study. The patients were divided into three groups as mild, moderate, and severe according to the Clinical 
Global Impressions Scale (CGI) in terms of severity of the disease. The control group was formed by 40 volunteers who were like the patient group in terms of age and gender.

Clinical Global Impressions Scale (CGI): Developed by Guy, CGI is a three-dimensional scale to enable the clinician to record the impression of the patient's functionality before and after treatment. The severity of the disease in the first dimension of the scale, the recovery in the second dimension, and the severity of the drug side effect in the third dimension are evaluated. The first dimension of the scale was performed in study. 15

\section{Exclusion criteria}

Smokers, patients with alcohol and substance use, additional psychiatric disease, acute or chronic disease (diabetes mellitus, hypertension, chronic renal failure, etc.), patients with a focus of infection.

Venous blood samples of approximately $5 \mathrm{ml}$ were collected from the patient and control groups to the biochemistry tubes. The samples were kept at room temperature for 5-10 minutes and then centrifuged at $4000 \mathrm{rpm}$ for 5 minutes. The supernatant (serum) formed on top was portioned into Eppendorf tubes and kept at -80OC until tests were performed. After providing the number of patients required for the study, all the samples were taken out of $-800 \mathrm{OC}$ to defrost, human CYCS (cytochrome $\mathrm{C}$ ), human granzyme $\mathrm{B}(\mathrm{GrB})$ and human caspase-8 (C-8) tests were performed in the ELISA device.

Approval was obtained from the Ethics Committee of Cumhuriyet University Faculty of Medicine by the decision numbered 2018-06/01 on June 28th, 2018, and required permissions were obtained from Sivas Numune Hospital Chief Physician. The participants were informed about the study, and the consent forms were received in writing.

\section{Statistics}

Obtained data (C-8, CYCS, and GrB) were loaded into SPSS 22.0 program. Test of normality was proved by Kolmogorov Smirnov Z test. As all the results were in the $95 \%$ confidence interval, the distributions were assumed normal. Having data sets suitable for normal distribution; betweengroup differences test the independent samples Ttest (student $\mathrm{T}$ ) was performed. The mean difference between the groups was statistically determined in all variables. Since the number of data was less than 30 , comparisons between the control group and disease severity were performed by Kruskal Wallis-H Test and Mann Whitney u test.

\section{RESULTS}

The study group consisted of 60 volunteers who were diagnosed with schizophrenia, and the control group was composed of 40 volunteers. The patients were divided into three groups as mild, moderate, and severe according to the Clinical Global Impressions Scale (CGI) in terms of severity of the disease. There was no statistically significant difference between the patient and control groups in terms of age and sex $(\mathrm{p}=0,874)$ (Table 1). The patients diagnosed with schizophrenia had a significantly $(\mathrm{p}<0.05)$ higher CYCS and lower caspase-8 and GrB levels compared to the control group (Table 2). The average of Caspase- 8 values is gradually decreasing from control to schizophrenia severe group. The groups are compared with two pairs; The difference between the control and mild group, and the moderate and severe groups were not statistically significant ( $p>0.05)$. The difference between the other groups was statistically significant $(\mathrm{p}<0.05)$ (Table 3$)$. The average of CYCS values increases from control to clinically severely defined groups. When the groups are compared in two pairs; The difference between control and mild, control and moderate, and mild and moderate groups was not statistically significant ( $p>0.05)$. The difference between the other groups was statistically significant $(\mathrm{p}<0.05)$ (Table 4). The average of GrB values decreases from control to severely schizophrenia groups. When the groups are compared with two pairs, the difference between the control and the other three schizophrenia groups (mild, moderate, and severe) was statistically significant $(p<0.05)$. In addition, the difference between the Light and severely schizophrenia groups were statistically significant (p <0.05) (Table 5). 
Table 1: The gender ratio of the groups

\begin{tabular}{|lcccl|}
\hline Gender & Female & \% & Male & \% \\
\hline Control $_{\mathbf{n}=\mathbf{4 0}}$ & 19 & 47.5 & 21 & 52.5 \\
\hline Patient $_{\mathbf{n}=\mathbf{6 0}}$ & 27 & 45.0 & 33 & 55.0 \\
\hline
\end{tabular}

No statistically significant difference between the patients with schizophrenia and the control group was observed in terms of age and gender. $(\mathrm{P}=0,874)$

Table 2: Caspase-8, Granzyme B, Cytochrome C Levels

\begin{tabular}{|lllllllllll|}
\hline \multicolumn{9}{c|}{ Control $(\mathbf{n}=\mathbf{4 0})$} & \multicolumn{7}{c|}{ Patient $(\mathbf{n = 6 0})$} \\
\hline & Mean & \multicolumn{2}{l}{ SD \pm} & Min. & Max. & Mean & SD \pm & Min. Max. & P & \\
\hline Age & 45.53 & 6.44 & 20 & 65 & 47.37 & 8.93 & 22 & 66 & $>0.005$ & \\
\hline Caspase-8 & & 3.620 & 0.270 & 3.140 & 3.980 & 3.210 & 0.490 & 2.310 & 3.980 & $<0.005$ \\
\hline CYCS $_{\text {pg/ml }}$ & 1.330 & 0.089 & 1.22 & 1.560 & 1.433 & 0.226 & 1.03 & 2.340 & $<0.005$ & \\
\hline GrB $_{\text {pg/ml }}$ & 50.05 & 7.681 & 33.49 & 65.08 & 42.89 & 7.421 & 32.83 & 62.84 & $<0.005$ & \\
\hline
\end{tabular}

It was found statistically significant that the CYCS levels of patients diagnosed with schizophrenia were higher and caspase- 8 and GrB levels were lower than control group $(\mathrm{P}<0.05)$.

Table 3: Caspase-8 levels in terms of severity of schizophrenia

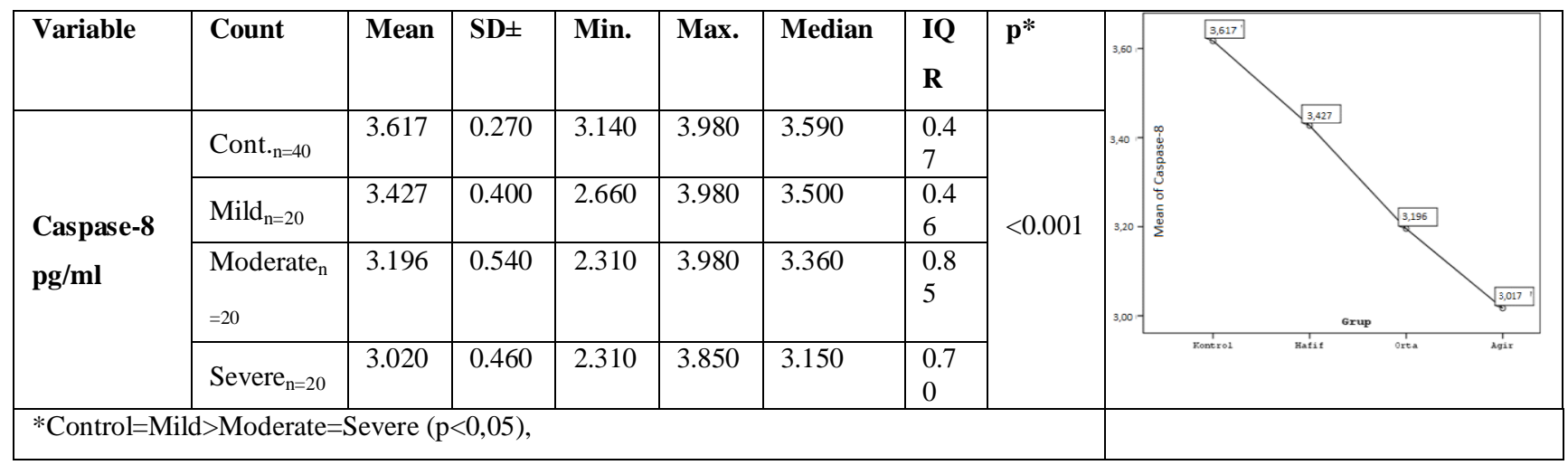

The mean Caspase- 8 values are decreasing from control groups to severe groups. It was not found statistically significant the difference between Control and Mild Groups and Moderate and Severe Groups, either $(\mathrm{P}>0.05)$. The differences between control and moderate, control and severe, mild and moderate, mild, and severe groups were found statistically significant $(\mathrm{P}<0.05)$.

Table 4: CYCS levels in terms of severity of schizophrenia

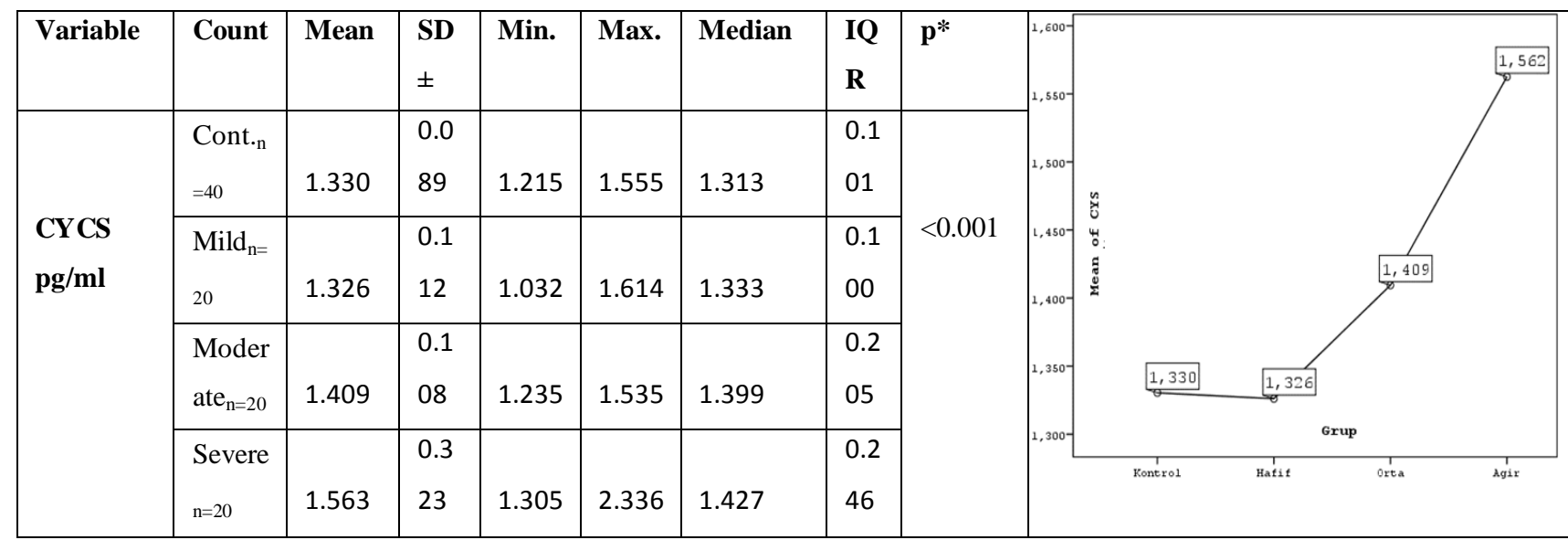

The mean CYCS values are decreasing from control groups to severe groups. It was found statistically significant that mean of severe group was higher than the other groups $(\mathrm{P}<0.05)$. However, the difference between the other three groups (control, mild and moderate) was not found statistically significant $(\mathrm{P}>0.05)$. 
Table 5: GrB levels in terms of severity of schizophrenia

\begin{tabular}{|c|c|c|c|c|c|c|c|c|c|}
\hline Variable & Count & Mean & $\mathbf{S D} \pm$ & Min. & Max. & Median & IQR & $\mathbf{p}^{*}$ & \multirow{6}{*}{$\overbrace{\text { orup }}^{50,05}$} \\
\hline \multirow{4}{*}{$\begin{array}{l}\text { GrB } \\
\text { pg/ml }\end{array}$} & Cont $_{. n=40}$ & 50.053 & 7.681 & 33.490 & 65.080 & 49.540 & 5.640 & \multirow{4}{*}{$<0.001$} & \\
\hline & Mild $_{n=20}$ & 46.032 & 7.818 & 33.490 & 62.840 & 44.380 & 5.960 & & \\
\hline & Moderate $_{\mathrm{n}=20}$ & 42.868 & 7.414 & 32.830 & 56.120 & 44.380 & 13.495 & & \\
\hline & Severe $_{\mathrm{n}=20}$ & 39.763 & 5.852 & 32.830 & 49.540 & 36.910 & 10.420 & & \\
\hline \multicolumn{9}{|c|}{$*$ Control $>$ Mild $\geq$ Moderate $=$ Severe $\mathrm{p}<0.05$} & \\
\hline
\end{tabular}

The mean GrB values are decreasing from control groups to severe groups. The difference between control and the other three groups (control, mild and moderate) was found statistically significant $(\mathrm{P}<0.05)$. Also, the difference between Mild and Severe Groups was found statistically significant $(\mathrm{P}<0.05)$. However, the difference between Moderate and Mild, Moderate, and Severe was not found statistically significant $(\mathrm{P}>0.05)$.

\section{DISCUSSION}

In the development and pathophysiology of the nervous system, the death of neural cells is critical. Apoptosis is important for neural cells, which were aging and damaged. This constitutes the control mechanism of neural development. ${ }^{16}$ Some schizophrenic patients have been shown to gradually lose gray matter in the frontal and temporal lobes of the brain by using noninvasive neuroimaging methods. The cellular mechanisms responsible for the loss of gray matter are not known. It is suggested that apoptosis may account for this condition. ${ }^{17}$

Considered previous literature researches, a limited number of articles have been found on the gene expression level by polymerase chain reaction (PCR) and imaging methods to demonstrate apoptosis in patients with schizophrenia. In addition, biochemical studies showing the relationship between schizophrenia and apoptosis are quite limited. As with many diseases, the determination of blood-based biomarkers will be an important milestone in the diagnosis or treatment of schizophrenia.

It was reported that glycolysis accelerated, levels of oxidative stress and lactic acid. ${ }^{18-22}$ increased, the Bcl-2 level decreased in the temporal cortex compared with controls, and the Bax/Bcl-2 ratio increased in patients with schizophrenia according to studies. Increase in mitochondrial cytochrome-c release resulting from the increase in $\mathrm{Bax} / \mathrm{Bcl}-2$ ratio improves the sensitivity of apoptotic activity. ${ }^{10,23}$

The aim of this study was to determine how apoptosis biomarkers are affected by patients with schizophrenia and the severity of the disease and whether apoptosis is a blood-based biomarker that can be used to diagnose the disease.

Many studies have shown that serum cytochromec levels can easily be measured to evaluate the severity of the condition characterized by cell death. ${ }^{24}$ In this study, it was determined that there was a statistically significant increase in CYCS levels in patients with schizophrenia in comparison with the control group ( $p<0.05$ ) (Table 2). In terms of the severity of the disease, it was observed that there was a significant increase in all three groups, and the highest increase was observed in the third group (Table 4). The high level of cytochrome-C is thought to be a result of mitochondrial dysfunction in patients with schizophrenia. ${ }^{25}$ The results related to cytochrome-c of this study are in parallel with the results of the researchers mentioned above. The increase in cytochrome-c level is suggested to be the result of oxidative stress and downregulation of Bcl-2.

Apoptosis cascade is known to be induced by Cytotoxic T cells (CTL) by activating procaspases when linked to receptors of cell surface molecules belonging to the Fas Ligands (FasL) or TNF (Tumor Necrosis Factor) family. ${ }^{26,27}$ The activation of the pathways, in particular, caspase- 8 and $\mathrm{GrB}$, affects the mitochondrial membrane, thereby increasing cytochrome-c release. Increases in cytoplasmic cytochrome-c and caspase-8 levels are known to induce apoptosis by activating procaspase ${ }^{3-9.28}$ Although cytochrome-c levels were found statistically significant in this study, serum GrB and caspase 8 levels decreased in patients with schizophrenia compared with the control group ( $\mathrm{p}<0.05)$ (Table 2). It was reported by Jarskog LF et al. that the increase in Bax/Bcl-2 ratio in patients with schizophrenia increased the level of cytochrome-c, but not caspase-3.7 High level of cytochrome-c is associated with cell vulnerability to apoptosis, low levels of caspase- 8 and $\mathrm{GrB}$, on the other hand, suggest that apoptosis is not active, which is a paradox.

Possible causes of this paradox, 1-apoptosis can only be active in different stages of the disease. 
For example, apoptotic markers may be found to be high in the samples taken at the time of excessive volume loss of gray matter but may be found to be low in low volume loss. 2- In case the synaptic loss mediated by apoptotic protein activity in schizophrenia is episodic rather than constant, levels of caspase-8 and GrB may only temporarily increase and then return to the reference line. 3- Moreover, antipsychotic drugs used in the treatment of schizophrenia may also affect the apoptotic markers' expression, activity, or method of measurement.

Findings from studies related to brain tissue have not yet been transformed into biomarkers that are practical in clinical use. Because brain biopsies are not acceptable and neuroimaging techniques are expensive, and the results are unsatisfactory. Blood-based biomarkers are used in clinical biochemistry to diagnose many diseases, determine the severity of the disease, and evaluation of response to treatment. However, since blood interacts with all tissues, this leads to blood to form a pool for metabolic products and medical treatment metabolites of all tissues. Since this leads to many mistakes, blood-based biomarkers are often used as screening tests. In case the results for screening test are high, then a specific test is recommended.

\section{CONCLUSION}

It is hypothesized that the increase in serum CYCS level of patients with schizophrenia may be a blood-based biomarker in which apoptosis occurs. However, further studies are needed to clarify the paradox in this group of patients associated with an increase in CYCS levels and a decrease in caspase- 8 and GrB levels. This study is a preliminary study of future studies to be carried out about this subject, and it will shed new light on future studies. Biomarkers associated with apoptosis in blood, CSF, and tissue samples in schizophrenia-generated animal models are planned to be studied in the next study.

Our study has certain limitations: According to schizophrenia patients presenting to a psychiatric clinic, a large sample study is needed to confirm the results of this study.

Ethics committee approval: The study was carried out with written the approval (No: 201603/04) of the Ethics Committee of Cumhuriyet University.

Competing interests: The authors declared that there is no conflict of interest in the preparation and publication of this article.
Financial support: The authors declared that they did not receive any financial support while research and writing of this article.

\section{REFERENCES}

1- Öztürk MO, Uluşahin NA. Ruh Sağlığı ve Bozuklukları (14. baskı). Ankara: Nobel tıp kitabevleri; 2016.S:242-243

2- Yavuz R. Şizofreni İ.Ü. Cerrahpaşa Tıp Fakültesi Sürekli Tıp Eğitimi Etkinlikleri 2008 S:49-58.

3- Velásquez E, Nogueira FCS, Velásquez I, Schmitt A, Falkai P, Domont GB, et.al. Synaptosomal Proteome of the Orbitofrontal Cortex from Schizophrenia Patients Using Quantitative Label-Free and TRAQ-Based Shotgun Proteomics J Proteome Res. 2017:1;16(12):4481-4494.

4- Soygür H, Alptekin K, Atbaşoğlu EC, Herken H. Şizofreni ve Diğer Psikotik Bozukluklar. Ankara: Türkiye Psikiyatri Derneği; 2007. S:12

5- Vyas NS, Patel NH, Nijran KS, Al-Nahhas A, Puri BK. Can PET/CT imaging advance our understanding of the neurobiology of schizophrenia? Nucl Med Commun 2010;31(2):91-93.

6- Shenton ME, Dickey CC, Frumin M, McCarley RW. A review of MRI findings in schizophrenia. Schizophr Res 2001;49:(1-2):1-52

7- Jarskog LF, Selinger ES, Lieberman JA, Gilmore JH. Apoptotic proteins in the temporal cortex in schizophrenia: high $\mathrm{Bax} / \mathrm{Bcl}-2$ ratio without caspase-3 activation. American Journal of Psychiatry 2004;161(1):109-115.

8- Ow YP, Green DR, Hao Z, Mak TW. Cytochrome c: functions beyond respiration. Nat Rev Mol Cell Biol. 2008;9(7):532-542.

9- Yuan J, Yankner BA. Apoptosis in the nervous system. Nature 2000;407(6805):802-809.

10- Oltvai ZN, Milliman CL, Korsmeyer SJ, Bcl-2 heterodimerizes in vivo with a conserved homolog, bax, that accelerates programmed cell death. Cell 1993;74(4):609-619.

11- Sastry PS, Rao KS, Apoptosis, and the nervous system. J. Neurochem. 2000;74(1):1-20.

12- Cryns V, Yuan J: The cutting edge: caspases in apoptosis and disease. In When Cells Die. Edited by Lockshin RA, Zakeri Z, Tilly JL. New York: Wiley-Liss Inc; 1998:177-210.

13- Fu TM, Li Y, Lu A. Li Z, Vajjhala PR, Cruz AC, et.al. Cryo-EM Structure of Caspase-8 Tandem DED Filament Reveals Assembly and Regulation Mechanisms of the Death-Inducing Signaling Complex. Mol Cell. 2016:20;64(2):236250.

14- Dickens LS, Boyd RS, Jukes-Jones R, Hughes MA, Robinson GL, Fairall L, et.al. A death 
effector domain chain DISC model reveals a crucial role for caspase-8 chain assembly in mediating apoptotic cell death. Mol Cell. 2012: 27;47(2):291-305.

15- Guy W. ECDEU Assessment Manual for Psychopharmacology (028 Clinical Global Impressions [CGI]) Rockville, MD: NationalInstitutes of Health. 1976;218-222.

16- Mazarakis ND, Edwards AD, Mehmet H. Apoptosis in neural development and disease. Arch Dis Child Fetal Neonatal Ed. 1997;77(3):165-70.

17- Csernansky JG. Neurodegeneration in schizophrenia: evidence from in vivo neuroimaging studies. Scientific World Journal. 2007;7:135-143.

18- Dogan AE, Yuksel C, Du F, Chouinard VA, Öngür D. Brain lactate, and $\mathrm{pH}$ in schizophrenia and bipolar disorder: a systematic review of findings from magnetic resonance studies. Neuropsychopharmacology. 2018;43(8):16811690.

19- Rowland LM, Pradhan S, Korenic S, Wijtenburg SA, Hong LE, Edden RA, et.al. Elevated brain lactate in schizophrenia: a $7 \mathrm{~T}$ magnetic resonance spectroscopy study. Transl Psychiatry. 2016;6(11):e967.

20- Faizi M, Salimi A, Rasoulzadeh M, Naserzadeh P, Pourahmad J. Schizophrenia induces oxidative stress and cytochrome $\mathrm{C}$ release in isolated rat brain mitochondria: a possible pathway for induction of apoptosis and neurodegeneration. Iran J PharmRes. 2014;13:93100.

21- Rice MW, Smith KL, Roberts RC, PerezCostas E, Melendez-Ferro M. Assessment of cytochrome $\mathrm{C}$ oxidase dysfunction in the substantia nigra/ventral tegmental area in schizophrenia. PLoSOne. 2014;9(6):100054.

22- Pasdois P, Parker JE, Halestrap AP. The extent of mitochondrial hexokinase II dissociation during ischemia correlates with mitochondrial cytochrome c release, reactive oxygen species production, and infarct size on reperfusion. J AmHeartAssoc. 2012;2(1):e005645.
23- Jarskog LF, Gilmore JH, Selinger ES, Lieberman JA. Cortical bcl-2 protein expression and apoptotic regulation in schizophrenia. Biol. Psychiatry 2000;48(7): 641-650.

24- Eleftheriadis T, Pissas G, Liakopoulos V, Stefanidis I. Cytochrome c as a Potentially Clinical Useful Marker of Mitochondrial and Cellular Damage. Front Immunol. 2016;7:279.

25- Djordjević VV, Ristić T, Lazarević D, Cosić $\mathrm{V}$, Vlahović P, Djordjević VB. Schizophrenia is associated with increased levels of serum Fas and FasL. Clin. Chem. Lab. Med. 2012;50(6):10491054.

26- Goldsmith DR, Haroon E, Miller AH, Strauss GP, Buckley PF, Miller BJ. TNF- $\alpha$ and IL-6 are associated with the deficit syndrome and negative symptoms in patients with chronic schizophrenia. Schizophr Res. 2018: 2018;199:281-284.

27- Thomas DA, Du C, Xu M, Wang X, Ley TJ. DFF45/ICAD can be directly processed by granzyme $\mathrm{B}$ during the induction of apoptosis. Immunity. 2000;12(6):621-632.

28- Jeong JH, Kim DK, Lee NS. Jeong YG1, Kim HW2, Kim JS, et.al. Neuroprotective Effect of Nortriptyline in Overt Hepatic Encephalopathy Through Attenuation of Mitochondrial Dysfunction. ASN Neuro. 2018;10: 1759091418810583 